\title{
Developing autonomous listening learning materials for TOEFL preparation
}

\author{
Makan Sacko *, Youssouf Haidara \\ Centre des Langues de Badalabougou, Bamako, Mali \\ * Coresponding Author. E-mail: maquennsie@yahoo.fr \\ Received: 26 July 2016; Revision: 13 August 2018; Accepted: 25 December 2018
}

\begin{abstract}
This research was aimed at developing autonomous listening learning materials for TOEFL preparation for learners at independent language learning center (ILLC) of the language development center at UNY to assist in improving their listening skills. This research is a Research and Development study which refers to development model proposed by Tomlinson (2011). The subjects of this research were 30 students who are members of ILLC. Data were collected using questionnaires and open-ended interviews. The data were analyzed qualitatively and quantitatively. The results of the research reveal that the appropriate listening learning materials for TOEFL preparation consist of printed materials and audio recording containing the listening skills to find the main topic, the main idea, and the implied meaning, to make prediction, to determine the meaning of idiomatic expressions, to locate detailed information, to draw conclusions, to identify suggestions, and to make inferences. The learners' role is as active listeners and to answer multiple choice questions, the learning activities include many listening practices, clear instructions, reflection and answer keys. Units are designed to consist of Unit number/title, learning objectives, hints/tips, main activities and reflection. The appropriate tasks consist of warming-up, matching expressions to the pictures, matching words to their meanings, guessing, anticipating the topics and or questions, listening practices, and note-taking.
\end{abstract}

Keywords: listening, autonomous learning, TOEFL, materials

How to Cite: Sacko, M., \& Haidara, Y. (2018). Developing autonomous listening learning materials for university students TOEFL preparation. LingTera, 5(2), 170-178. doi:https://doi.org/10.21831/lt.v5i2.10192

https://doi.org/10.21831/lt.v5i2.10192

\section{INTRODUCTION}

According to Sharpe $(2004$, p. 6$)$ students in preparing the standard test especially TOEFL need to be able to set goals that enable them a little practice every day for few months than a lot of practice concentrated in a shorter time. This means students have to be able to be autonomous learners in order to succeed in TOEFL. In general, all of the four language skills are tested in TOEFL. In the standard TOEFL test, listening is one of the sections and it is the section that many learners considered more stressful than the other sections.

Between the four language skills, listening is believed to be one of the most important language skills. It is also the first and yet the most difficult for many test-takers in the TOEFL test. Another important point is the TOEFL test. It is one of the most popular tests which are administered by universities across the world for different purposes. Richards (2008, p. 5) states that "now, university entrance exams, exit exams, and other examinations often include a listening component, acknowledging that listening skills are a core component of second-language proficiency, and also reflecting the assumptions that if listening isn't tested, teachers won't teach $i t$ " Through this statement the importance of listening is undeniable. Out of the lack of the learning materials, the researcher find what makes listening difficult for learners in general and English language learners in preparing TOEFL in particular. In developing autonomous English listening materials for TOEFL preparation, the researcher decides to provide appropriate printed materials for autonomous learners. In reference to that, it is of considerable interest to explore what are some possible ways to learn to listen in order to obtain a high score in TOEFL, especially in the listening section. Therefore, one of the clear solutions is promoting 


\section{LingTera, 5 (2), 2018 - 171}

Makan Sacko, Youssouf Haidara

learning autonomy to students to face the problems in both listening and TOEFL. Learner autonomy has come to be seen as increasingly important because it is linked to the successful development. In relation to that, Gardner (2011, p. 8) claims that being autonomous learner is to have the ability to set goals, implement strategies to attain goals, identify relevant resources, and access personal progress is advantageous for learning and facilitates the success. From the statement above, autonomous learner is learner who is able to take important decisions for his/her own. One example is to be able to identify his/her own weaknesses when preparing the TOEFL.

According to Jannejad, Shokouhi, and Haghighi (2012, p. 155) listening is the skill with which many learners feel the most uncomfortable. Furthermore, they add that this feeling is because of the pressure listening places on them to process input rapidly. However, there is a strategy to minimize this pressure. In reference to the issues above, this research aims at exploring the problems TOEFL students are facing and proposing autonomous learning as a solution to minimize those students pressure. Students need more practice and autonomous learning materials especially for TOEFL listening section. To do so, it means that the learning materials provide a large amount of exercise material and practices which enable learners to self-orientation, confidence, and autonomy to adapt the situation they are or will face (Cookson, Marchand, \& Rowlett, 2011, p. 199). Listening is not only recognized as a nonpassive process but also a complex receptive process. In account of that, a research conducted by Choirunnisa and Haryadi (2015, p. 210) underlined the idea that listening is considered by students of SMA/MA Yogyakarta as the skill that is difficult to master and less interesting. In addition, during the past fifty years, a particular attention has been paid to listening because of its importance in language acquisition and language learning. However, Schwienhorst (2003, p. 427) revealed that unlike the others language skills such as speaking writing and reading, listening has been neglected. And they added that listening can be developed even without assistance. We can understand here that learners can be autonomous easily in learning to listen. In addition, extensive and intensive listening are also claimed to be the common kinds of listening practice that help students to practice and improve their listening skills.

\section{METHODS}

Each autonomous learner searches for methods that she or he will adapt easily to achieve the goals and objectives s/he has set. Therefore, this study used the quantitative and qualitative methodology, which allows us to explore perceptions and processes in context. The participants were 30 members of ILLC and they are from different universities. All of them are eager to prepare TOEFL in order to get a high score which can meet the fulfillment of the universities' policy related to the TOEFL scored. In this research, we used questionnaires and interviews to gather information of students. The majority of the learners wish to have autonomous listening materials in printed materials with particular attention on some aspects of language such as grammar and vocabulary. For more clarity, this study has used the model of Tomlinson (2011, p. 10) that is under the umbrella of research and development (R\&D) used by Gall, Gall, and Borg (2003, p. 569). This method is an industry based development model used to design new products. The procedure used in this study is adapted from the model proposed by Jolly and Bolitho in Tomlinson (2011). There were some adaptations applied in order to meet the conditions of this research. The researcher have analyzed first many models in order to decide which model is suitable for this research. Therefore, the suitable model is the model of Tomlinson which consists of five steps. They are: Conducting the needs analysis, designing the syllabus, designing the first draft materials, conducting the expert judgment and designing the final draft materials.

\section{FINDINGS AND DISCUSSIONS}

The results of this study show that the autonomous learners need some basic competencies in the TOEFL listening section. The skills that the learners expect more include the listening skills such as to find detailed information, main topic, implied meaning, synonyms, and suggestions, to anticipate the topic/questions, to identify explicit and implicit information, to make prediction, to look for assumptions, questions about opinions, draw conclusions about who, where, what, when, the occupations and the relationships between the speakers, determine the questions about futures actions. In addition, there are listening skills such as to find the main idea, find the purpose of a conversation, find fact-based and inference information, understand the purpose, setting and questions in dialogs and monologs. 
Beside the first is Part A listening to short dialogs about Daily activities, social inside or outside the campus in America. The second is listening to longer conversations between two speakers about education, general daily activities and the third is listening to talks or lectures. Figure 1 present the needs of the learners.

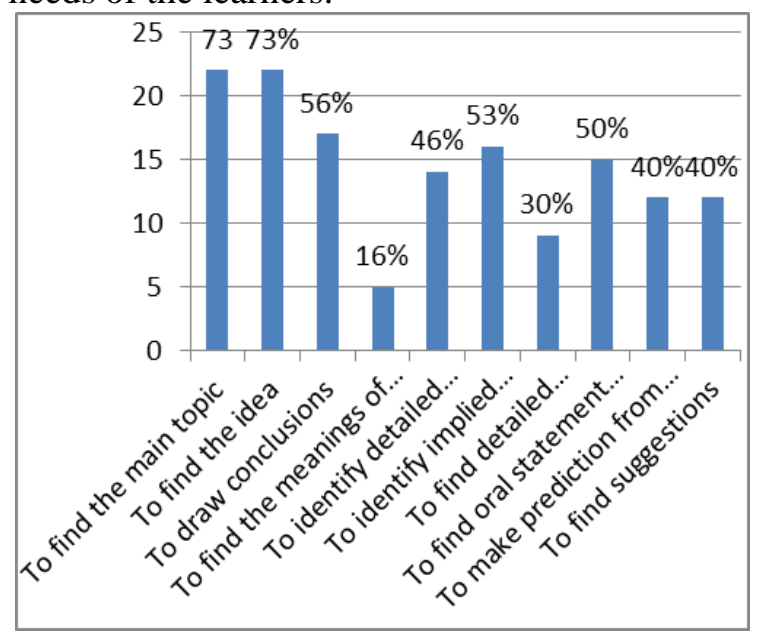

Figure 1. Listening Skills the Learners Need

Based on Figure 1, the listening skills that the learners need the most are as follows: to find main topic $73 \%$ of the learners said they need that, to find main idea $73 \%$, to find meaning of inferences $56 \%$ of the learners stated that they need that skill, to identify the implied information from a dialog/monolog 53\% think they need that skill, to determine an oral statement about place and attitude in a lecture $50 \%$ of the learners wish they need that skill, to find detailed information from a conversation $46 \%$ think they need that skill. Then, $40 \%$ of the students said they need the listening skill to predict meaning from a conversation about the lecture, another $40 \%$ think they need skills to find suggestions in a dialogue/ monolog and $30 \%$ of the learners stated they need to able to find details information from an academic conversation. And $16 \%$ wish to determine the meaning of idiomatic expressions. The interview also revealed that the above listening skills are the object of interest of the majority of the learners, 3 respondents out think they need these skills above.

Figure 2 shows that the learners are interested in almost all of the topics proposed. Out of 30 learners $(80 \%)$ wished the topic about daily activities, $(76 \%)$ wished the topic about education, $66 \%$ of the learners wished the topic of travel and tourism, $50 \%$ of the learners wished the topic about American culture in the materials, and another $50 \%$ of the learners wished the topic about lecture. For the topic of sport, $40 \%$ of the learners wish it must include the materials and $36 \%$ of the learners liked the topic about politics. Only $6 \%$ of the learners wished others and they mentioned the topic of engineering, technology and watching the film.

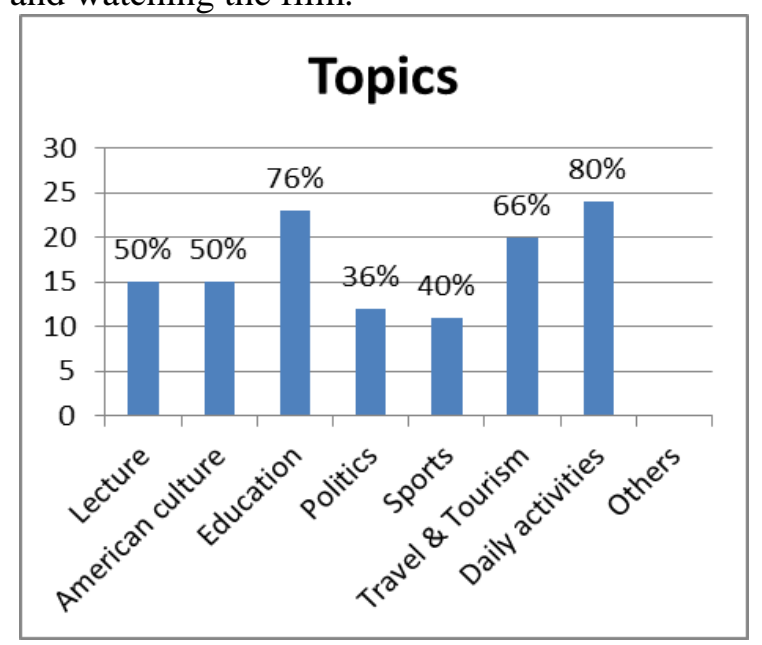

Figure 2. The Topics Needed

The interview has revealed that $100 \%$ of the respondents think they need texts with topics about daily activities, education, lecture, American culture, travel \& tourism. In conclusion, the materials will contain the topics in order of priority by considering the highest percentage first.

\section{Lacks}

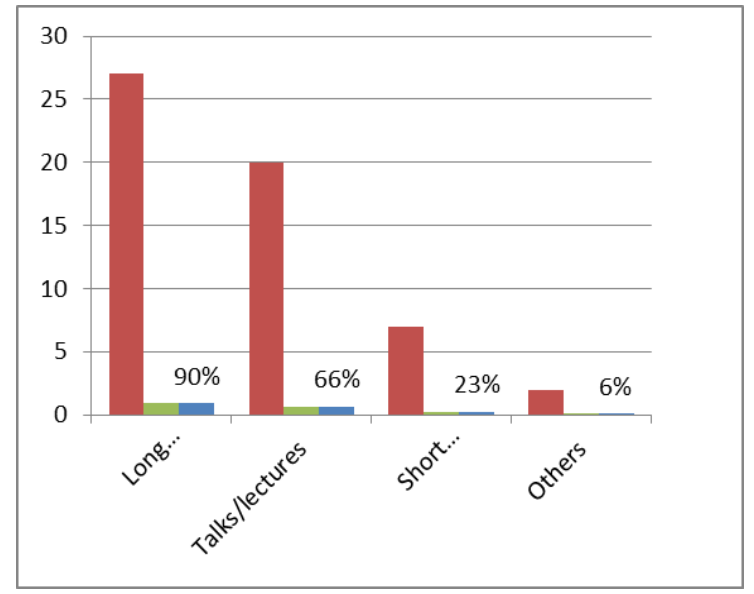

Figure 3. The Skills that the Learners have not Mastered Well

Based on the information in Figure 3, 90\% of the learners stated they have not mastered long conversation, $66 \%$ of the learners have not yet mastered talks/lecture, $23 \%$ of the learners said they have not mastered the short dialogs/mono$\operatorname{logs}$ and finally $6 \%$ of the learners think the others, however, they mention: Idiom and pronunciation. The interview has revealed that $50 \%$ of the respondents think they have not mastered 
to find information from a long conversation and lecture. In conclusion, much attention is paid to the long conversation then come to the talks/ lectures and then the short dialogs.

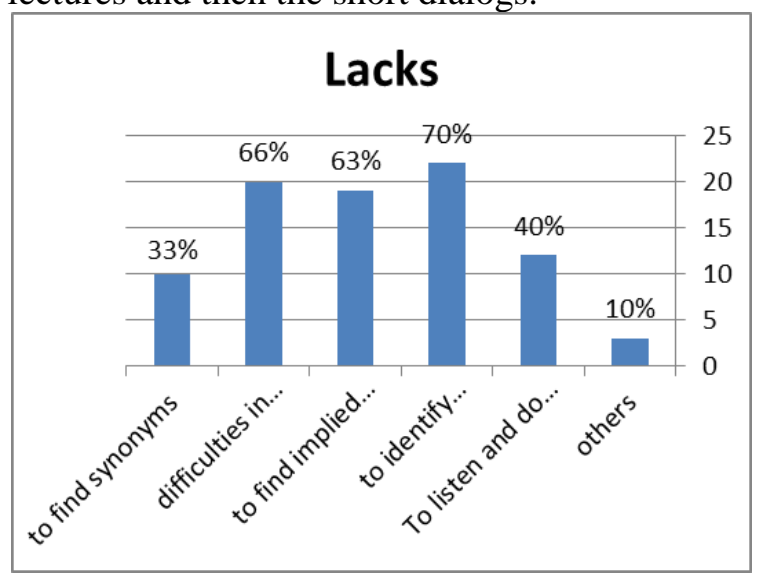

Figure 4. Problems in Listening

Based on the information in Figure 4, 70\% of the learners said they have problems because they said they do not know the synonyms of many words, $60 \%$ of the learners said that they do not like very long recording, $56 \%$ of the learners wrote that they did not have enough strategies to do the tasks effectively and $36 \%$ think that the method of talks/lecture is very difficult, another $36 \%$ of the learners wrote that they do not have autonomous listening books to learn autonomously. After that, $33 \%$ of the learners did not know much vocabulary, $30 \%$ of the learners said that they did not have listening printed materials. Finally, 23\% of the learners stated they did not know much grammar. The data found from the open-ended interview revealed that all the respondents $100 \%$ have problems to find the main idea/topic, $20 \%$ think it is difficult to find detailed information and synonyms, 20\% think it is difficult to find suggestions and inferences from dialogs/monologs, $50 \%$ of the respondents found it difficult to listen to lecture, $50 \%$ think they do not have printed materials, $20 \%$ think it is difficult to listen to longer conversation.

According to Figure 5, 70\% of the learners have difficulty to find synonyms in a conversation, $66 \%$ of the learners have difficulty in recalling after listening. Meanwhile, $63 \%$ of the learners find it difficult to find implied meaning, $40 \%$ of the learners also have difficulty in identifying inferences then $33 \%$ of the learners find it difficult to listen and do the task at the same time and finally, $10 \%$ of the learners wish the others and they mention: "pronunciation", "Idiomatic sentences" and "idioms".

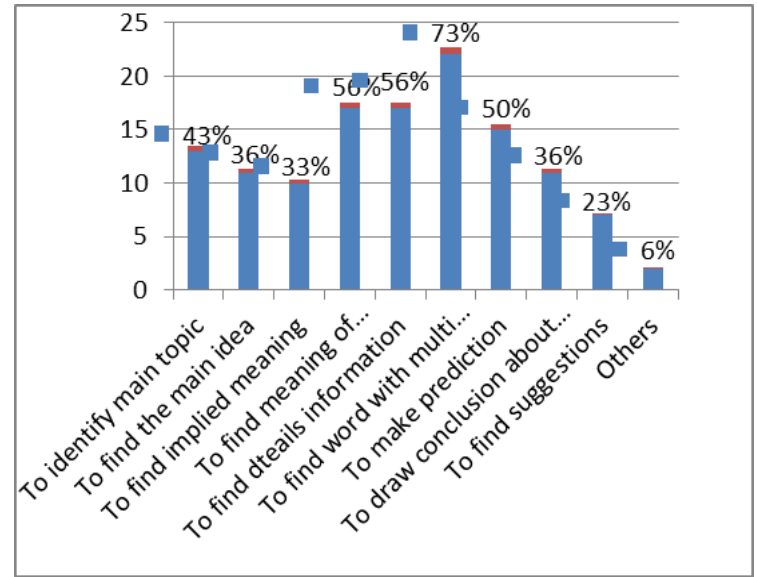

Figure 5. Things the Learners Need to Master

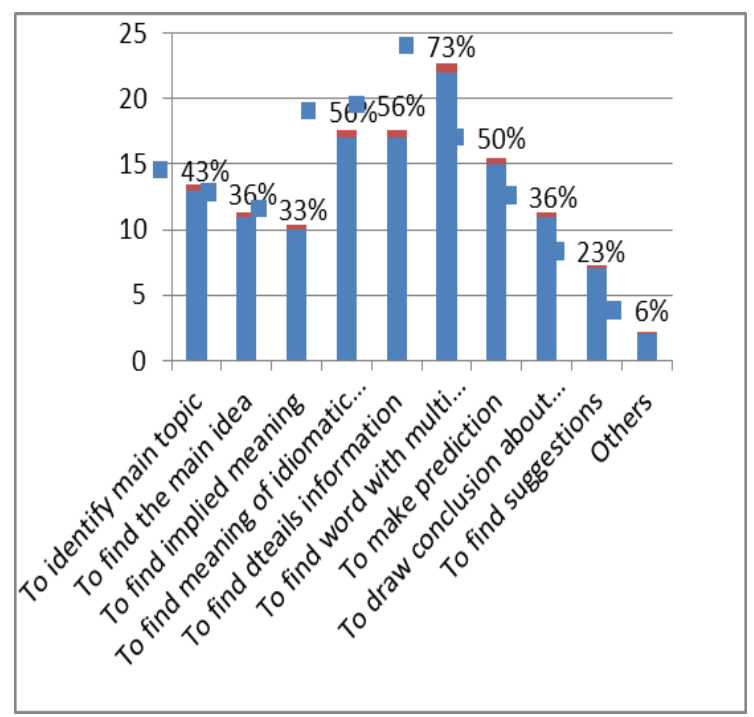

Figure 6. Listening Sub-Skills

Figure 6 shows the listening sub skills the learners wish the most; $73 \%$ of them wish to be able to find the implicit information, $56 \%$ of the learners need to be able to find meaning from idiomatic expressions, $56 \%$ of the learners think it is important to be able to find detailed information in a conversation, $50 \%$ wish they are able to make prediction, As for the ability to find main topic, $43 \%$ of the learners wish they have that sub-skill, after that $36 \%$ want to be able to draw conclusion about who, where, what and when, $33 \%$ of the learners wish to able to find implied meaning, and $23 \%$ of the learners need to be able to identify suggestions. $6 \%$ of the learners wish the others. However, they did not mention them.

\section{TOEFL Score}

Related to the information about the learners' scores in TOEFL, we judge it necessary not to analyze them using -frequency table because a considerable number of the learners $(60 \%)$ have never sat for the TOEFL test while 
many of them did mention neither their TOEFL score in general nor the score in the listening section. However, almost all of the learners $(90 \%)$ want to have scored higher than 500 . The interview revealed that $20 \%$ respondents out of $100 \%$ said their TOEFL score is 300 they think the listening section was the lowest score and they are targeting 500, 20\% have never sat for TOEFL and they want the score of 500, $20 \%$ of the respondents has about 450, 40 in listening and is targeting 60 in listening.

\section{Wants}

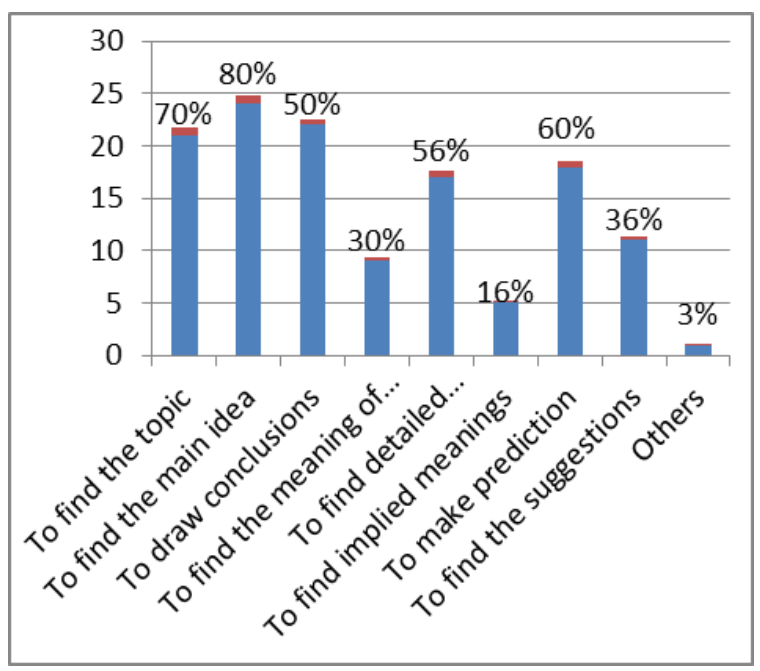

Figure 7. The Things that you want to Prioritize

From Figure 7, out of 30 learners, $80 \%$ of the learners want to prioritize finding the main topic in dialogs/monologs, $70 \%$ of them want to prioritize identifying the main idea, then $60 \%$ want to prioritize how to make prediction, $56 \%$ of the learners want the option to find detailed information in conversations, $50 \%$ of the learners want the option to determine inference meanings, $36 \%$ of the learners want the statement to determine suggestions. After that, $30 \%$ of the learners want the option to find the meaning of idiomatic expressions, $16 \%$ of the learners want to prioritize determining the implied meanings and $3 \%$ wish the others and they mention "details information".

In Figure 8, the learners' want in terms of input are as follows: $80 \%$ of the learners wish the input in the form of conversation in which we can find the main topic, $70 \%$ of the learners want inputs in the form of dialogues/monologs with a topic about education. Further, $63 \%$ of the learners hope more the input in the form of vocabulary list for listening into the context, 33\% wish input in the form of the recording containing classroom presentation, $13 \%$ of input in the form of a lecture in class and 3\% of the learners want the others. Therefore, they mentioned "Membaca lebih dahulu untuk belajar". The interviews revealed that $50 \%$ of the respondents wish the inputs in form recordings with tasks about to find the main topic in dialogs/monologs, $80 \%$ of the respondents wish the input in the form of printed materials containing vocabulary and synonyms.

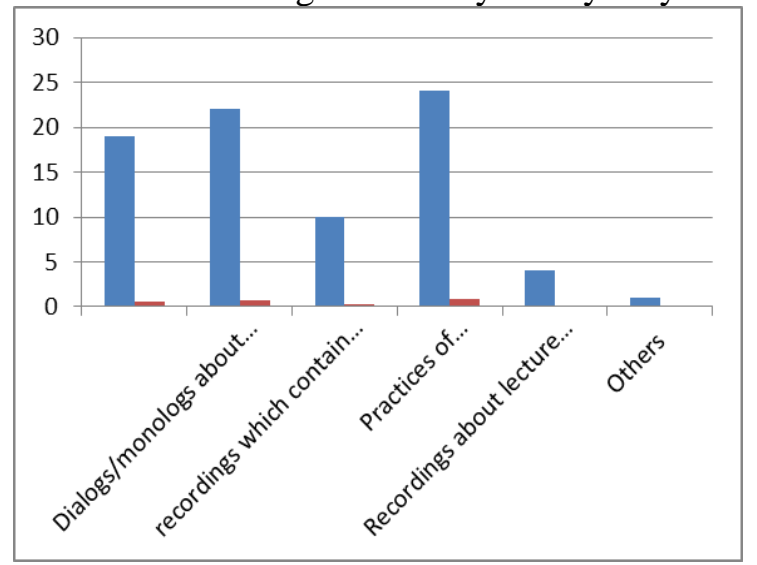

Figure 8. Input

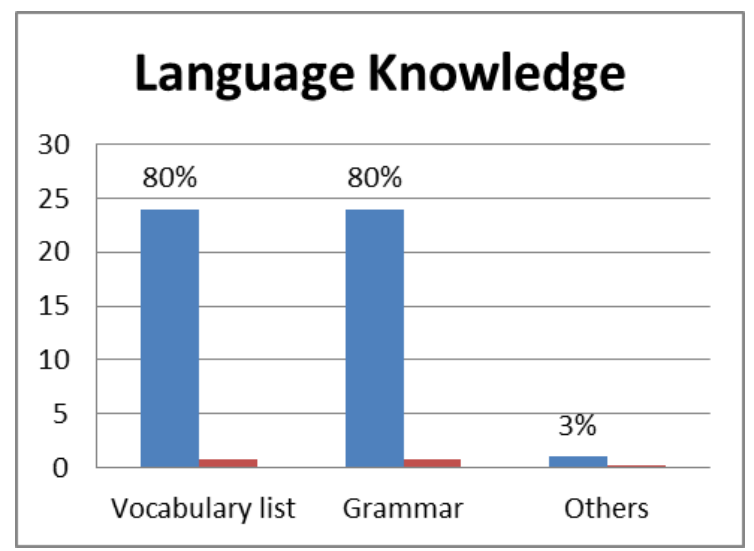

Figure 9. Language Knowledge

Based on Figure 9, the learners' preferences are as follows: $80 \%$ of the learners find it helpful to learn vocabulary in order study well the TOEFL listening section, 80\% show that it helpful to also study grammar for better learning the TOEFL listening section. Finally, only $3 \%$ preferred the others and they mentioned "pronunciation".

The information in Figure 10 indicates that $76 \%$ of the learners think that printed materials and transcript are the best media to learn to listen autonomously, $73 \%$ think of dialogs/monologs in the form of recording. Furthermore, $70 \%$ of the learners wish videos in English can help more for practicing listening. Besides that, 50\% of the learners think songs are good media for learning to listen and only $3 \%$ wish the others and they mentioned 'kurangnya vocabulary'. From the 
interview, $50 \%$ of the respondents wish the printed materials and watch TV in English, 20\% wishe voice recorder and watch TV, $20 \%$ wish.

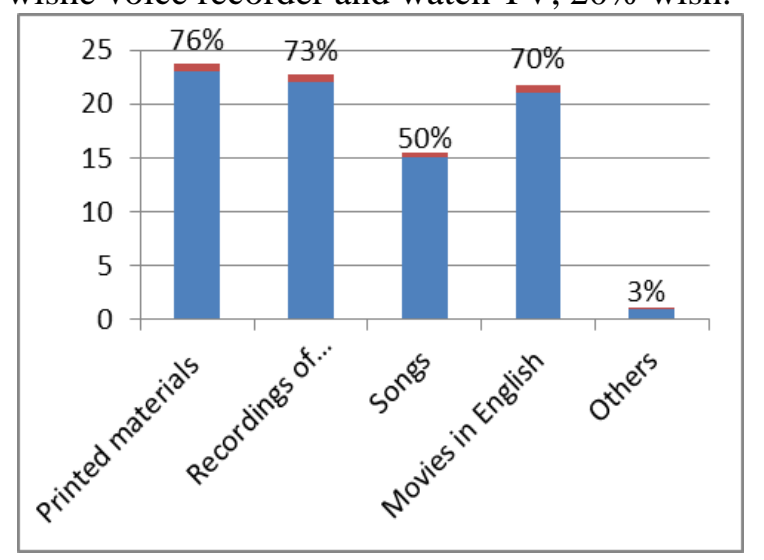

Figure 10. Listening Media for Success in TOEFL Listening Section

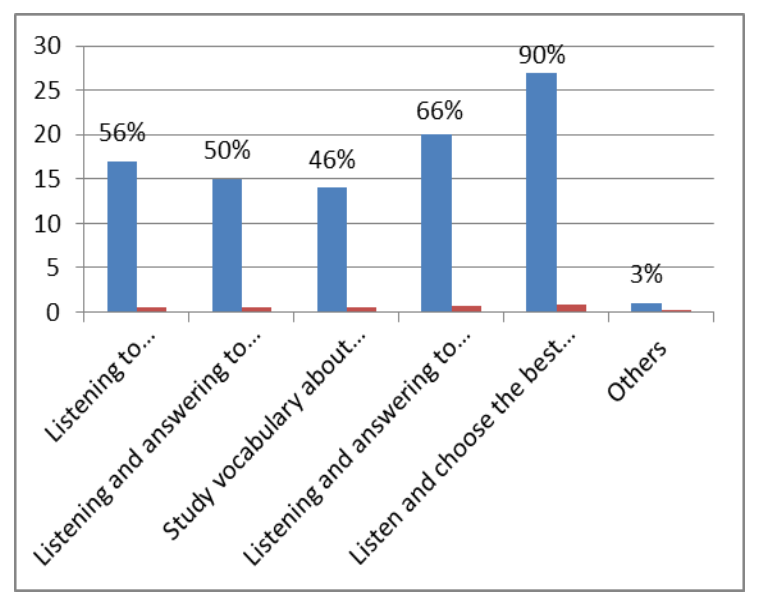

Figure 11. Effective Listening Learning Activities

Figure 11 indicates that $90 \%$ of the learners expect much listening to dialogs/monologs with many exercises, $66 \%$ preferred listening and predict. Besides these choices, $56 \%$ of the learners think that activities should contain learning vocabulary and their meaning in the printed book. $50 \%$ of the learners preferred listening and answering questions autonomously by using the printed material, $46 \%$ of the learners wish more listening and choose the best answer from multiple choice and 3\% wished the others. However, they did not mention any. The interview revealed that $80 \%$ of the respondents wish activities as listening tasks with many practices such as learning to recall after listening, to draw conclusions, to find implied meaning, and to find the meaning of idiomatic expressions as well and $20 \%$ wish listen and recalling information.

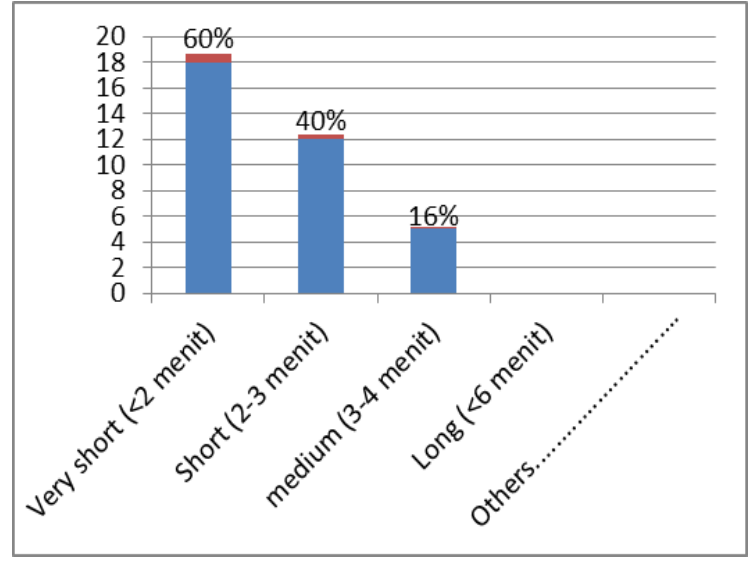

Figure12. The Length of the Dialogs and Monologs

Based on Figure 12, 60\% of the learners preferred the very short dialogs/monologs can help them much in the listening materials, $40 \%$ of the learners ticked the option short dialogs/ monologs in materials. Besides the short dialogs/ monologs, $16 \%$ of the learners said that medium dialogs/monologs will help much in the materials. The interview revealed that $2 / 4$ of the respondents dislike very long dialogs/monologs.

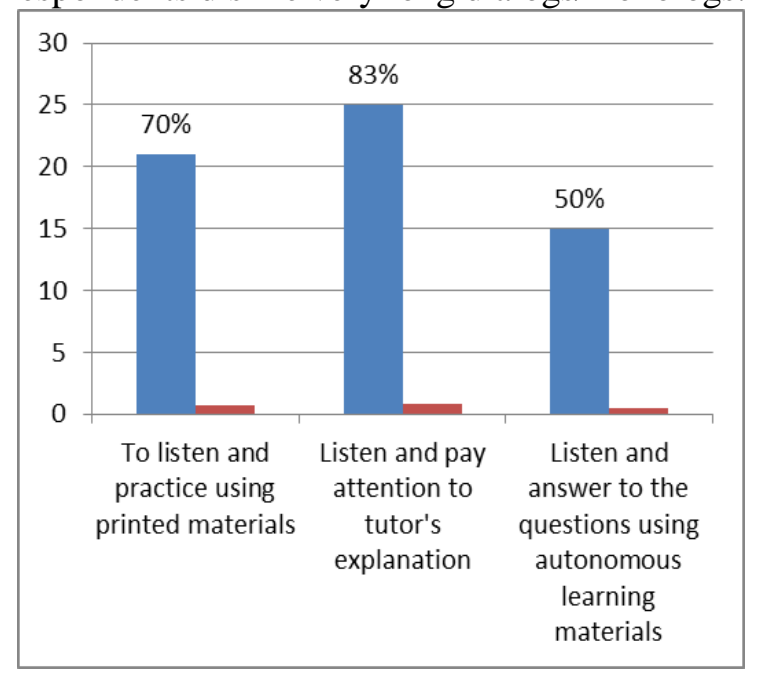

Figure 13. Learner's role

From Figure 13, 80\% of the learners wish learner's role as to listen and practice from printed book and answer to multiple choice questions, $70 \%$ of the learners hope learner's role as listening and pay attention to tutor's explanation whereas $50 \%$ of the learners wish learner's role as learning autonomously. From the interview, all of the respondents wish learner's role as to listen autonomously, $20 \%$ wish listen and pay attention to the instructor's explanation, $20 \%$ wish the instructor gives answer key and explanations if I cannot understand something, another $20 \%$ wish learn vocabulary, listen and answer using printed 


\section{LingTera, 5 (2), 2018 - 176 \\ Makan Sacko, Youssouf Haidara}

books and make prediction of sentences from them, and finally, another $20 \%$ of the learners wish understanding the words meanings.

\section{Tutor's Role}

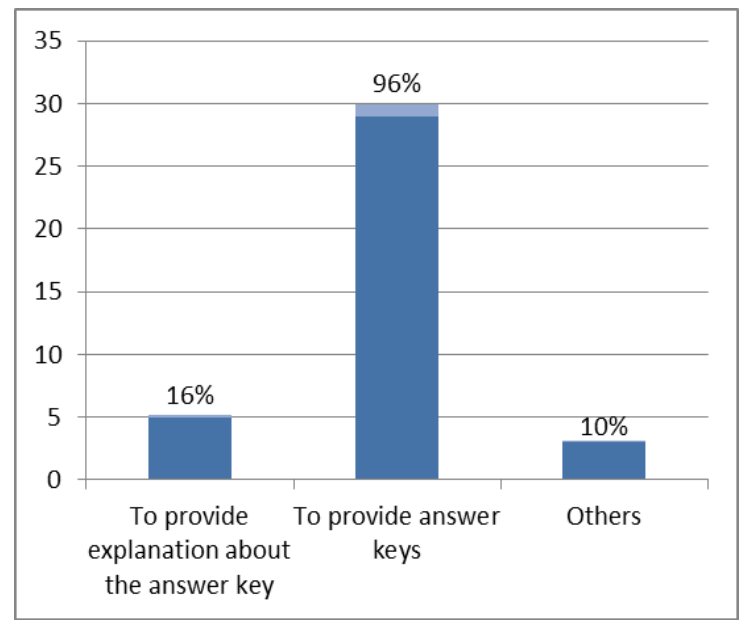

Figure 14. Tutor's Role

Figure 14 shows that $96 \%$ of the learners wish the role tutor as to give an explanation about the answers, $16 \%$ wished the tutor to give answer keys and $10 \%$ preferred the others and they mentioned: "Memberi arahan yang pelan-pelan, menjelaskan lebih rinci dan mendalam and menanya yang belum jelas kemudian dijelaskan".

The validation results by the materials and audio experts were presented in tables. They consisted of 26 statements categorized into seven groups based on the content appropriateness, language appropriateness, the learning activities appropriateness, the appropriateness of the topics and graphic, the appropriateness of the design and organization and the appropriateness of the methodology and audion.

Syllabus was the next step being developed after the results of needs analysis. It was designed based on needs analysis data. The syllabus contains the unit name and title, indicators, objectives, and the methods. In detail, the syllabus encloses the unit title, the listening subskills, strategies, topic, and input, learning activities, achievement, grammar, vocabulary, and sources.The unit titles in the materials taken based on the need analysis data. The process, in general, involves pre-listening, while-listening and post-listening activities.

According to the findings of this research the following are the aspects of the materials: First, The content, language, learning activities, the topics and graphic, the design and organization, the methodology and the audio are appropriate. They obtain the score of ... by the materials and audio experts which is considered as very good according to ....

Second, the autonomous listening learning materials for TOEFL preparation are appropriate in terms of topics and objectives, hints/tips, warm-up, main activities and reflection and answer keys. The data show that the learners showed good perception toward the product. However, some learners had given some comments and suggestions.

Third, the autonomous listening learning materials for TOEFL preparation should comprise of unit title, the objectives, hints/tips, warm up, main activities, and reflection.

\section{Unit Title}

The first part of the unit is the unit number/ title. The title aims at giving a general picture of the unit. After the title, there is a short description of the unit. It aimed at giving an indication of the unit. It includes the series, skill, level and the time of the unit so that the learners can set their own learning.

\section{Objectives}

The objectives give guideline about what the learners are going to learn in the unit. The next part after indicators and objectives is that of hints/tips.

\section{Hints/Tips}

This part is designed to enable the learners to have clear explanations and specific examples about the skills they are going to learn in the unit.

\section{Warm up}

The warm up consists of short questions, pictures or short dialogs/monologs about the topic. The warm up is aimed to help the learners to be ready for the main activities. The task sequence in warm up is to study expressions and pictures about the topic, after that there are main activities and those activities are followed by a reflection.

\section{Main Activities}

The main activities contain many sub-parts such as matching the words to their meanings, listening practices with multiple choice questions, and a grammar spot. The main activities are sequenced as follows: the learners are requested to match words to their meaning and then to listen to a recording and answer to multiple choice questions. The first sub-section is aimed to help the learners to do the listening practice effectively 


\section{LingTera, 5 (2), 2018 - 177 \\ Makan Sacko, Youssouf Haidara}

because it provides some inputs about the topic. The next subsection is designed to help the learners to practice and improve their listening skills. And then the next sub-section is grammar spot, it may provide the learners with useful languages, sentences or about tenses specific to listening activities. The grammar spot is aimed to help the learners to improve their grammar knowledge.

\section{Reflection}

The reflection part provides the learners chances to look back on the activities in the unit in order to record what they have learned from the unit and recognize points they need more practice on. After the reflection, there are summary and answer key. The summary gives the learners a brief resume about the important point in the unit. The last part is answer key; it permits the learners to check regularly their answers. For more details, the design of autonomous listening learning materials for TOEFL preparation is available in appendices.

Appropriate Tasks for Autonomous Listening Materials for TOEFL PreparationAs it was mentioned in previous parts, the developed materials consist of six units which vary on difficulties. Each unit comprises of several tasks such as warm up, matching expressions to the pictures, matching words to their meanings in English or in Bahasa Indonesia, guessing and anticipating the topics and questions, listening practices, repeat the words after the recording, etc. In addition, there are main activities which contain various inputs such as short/long conversation and mini-talks/lectures and note taking.

\section{CONCLUSION}

In conclusion, we explored some important things namely study, the result of needs analysis of the autonomous learners, the syllabus, the first draft of the materials, the validation results by materials and audio experts and the final draft or design of the ALLMTP. The autonomous learners have shown that it is of great importance to develop autonomous listening learning materials. First, learners are facing two main issues that are a lack of autonomous listening learning materials to improve their TOEFL listening skills. In regard to those issues, we suggested some solutions essential for helping learners become autonomous and face the TOEFL test with less anxiety. The first solution is to improve their listening comprehension by practicing as much as possible. Second, learners have to be efficient not only in choosing their own learning materials but also the learning time and environment. Finally, it is also important for the learners to be accustomed to the directions and strategies in the three parts of the listening comprehension.

Clearly, there is no doubt about the complexity of listening. Therefore, further research is needed in order to find out other solutions more effectively because different learners have different needs. Further investigation must be done to know about the learners' needs. It is also necessary to make our learners aware that the TOEFL listening is relatively easier compared to the real-life listening such as listening to radio, $\mathrm{TV}$, and announcements.

\section{REFERENCES}

Choirunnisa, S., \& Haryadi, H. (2015). Pengembangan media pembelajaran bahasa Inggris berbasis komputer untuk keterampilan menyimak bagi siswa SMA kelas X. LingTera, 2(2), 208 - 221. doi:https://doi.org/10.21831/lt.v2i2.7382

Cookson, S., Marchand, T., \& Rowlett, B. (2011). TOEFL skills, study abroad English and learner autonomy in the flight operations programme. In Search of a Learner-Centered Education, 11, 189-205.

Gall, M, D. Gall, J. P-\& Borg, W. R. (2003). Educational research: An introduction. (7th .Ed) New York: Pearson Education.Inch.

Gardner, D. (2011). Fostering autonomy in language learning. Zirve University. Hongkong.

Huntley, H. (1997). Longman introductory course for the TOEFL Test \& Longman preparation course for the TOEFL Test. Available from: http://www.zait.unibremen.de/wwwgast/test_ej/ej09/r6.html

Jannejad, M. Shokouhi, H. \& Haghighi, S. B. (2012). The effect of controlled language processing on listening comprehension and recall. Journal of English Teaching, 5(9), 155-165.

Richards, J.C. (2008). Teaching listening and speaking, from theory to practice. New York. Cambridge University press.

Schwienhorst, K. (2003). Learner autonomy and tandem learning: Putting principles into 


\section{LingTera, 5 (2), 2018 - 178}

Makan Sacko, Youssouf Haidara

practice in synchronous and asynchronous telecommunications environments.

Computer Assisted Language Learning, 16(5),

427-443. https://doi.org/10.1076/call.16.5.427.2948 4
Sharpe, P.J. (2004). Barron's how to prepare for the TOEFL test of English as a foreign language. (11th ed). Barrons Educational Series Inc.

Tomlinson, B. (2011). Materials development in language teaching. Cambridge University Press 